MATEUSz ĆWIKŁA

University of Humanities and Economics in Lodz, Poland

\title{
The delimitation of functional areas in Świętokrzyskie Voivodeship (Poland) concerning social, financial and economic as well as spatial and infrastructural criteria
}

\begin{abstract}
The article presents current trends in delimiting an area by function and covers various research issues. The main goal of the work was achieved through the author's method of delimiting functional areas in Świętokrzyskie Voivodeship, taking into account social, financial and economic, and spatial and infrastructural criteria. Among all 18 diagnostic features, the following indicators were the most useful: population density, net migration of permanent commune residents per 1000 population, non-working age population per 100 working-age, number of national economy entities on the REGON register per 1000 working-age population, number of dwellings per 1000 inhabitants, and proportion of commune agricultural land to total area. The starting point for creating a fixed classification for communes was the functional typology developed by J. Bański in 2009 at the special request of the Ministry of Regional Development. As a result of the delimitation, the following functional areas in Świętokrzyskie Voivodeship were designated: urban (5), diversified urban (7), tourist and spa (2), tourism and recreation (7), agricultural and horticultural (4), agricultural production (22), semi-subsistent smallholdings (30) and multifunctional (25).
\end{abstract}

Keywords: delimitation; functional areas; typology

Received: 16 December 2020

Accepted: 28 May 2020

\section{Suggested citation:}

Ćwikła, M. (2021). The delimitation of functional areas in Świętokrzyskie Voivodeship (Poland) concerning social, financial and economic as well as spatial and infrastructural criteria. Przedsiębiorczość - Edukacja [Entrepreneurship - Education], 17(1), 203-219. https://doi.org/ 10.24917/20833296.171.16

\section{Introduction}

Delimitation means identifying and spatially determining an area. It is a special type of classification that consists of setting boundaries by using two methods. The first is 
typology, based on finding homogeneous units or groups of units based on similarities or differences. The second is regionalisation, characterised by dividing larger parts into smaller ones due to differences and their boundaries or similarities (Śleszyński, 2016). In typology, designated classes are called 'types': a systematic (taxonomic) term denoting a group of tested objects with similar properties or characteristics. The similarity of the features that characterise a given phenomenon demonstrates that it belongs to a given type. The occurrence of given types is possible in the same area at different times and simultaneously but in different areas (Stola, 1987).

Typologies and territorial classifications are widely used, including in rural studies. The current EU financial plan for 2014-2020 justifies a division into different types, as the distribution of funds depends on qualifying for a given one. There are many typological concepts of rural areas in the literature, usually based on diagnostic indicators. Particular typologies are based on a specific grouping of determinants, and a basic one is a structural, locational and combinational approach (Bański, 2014).

The primary purpose of the discussion here is to develop the author's method of delimiting functional areas and is applied in Świętokrzyskie Voivodeship, taking into account social, financial and economic, as well as spatial and infrastructural criteria. The starting point for creating a fixed classification for communes was the functional typology developed by J. Bański in 2009 at the special request of the Ministry of Regional Development.

\section{Concepts of typology and the classification of functional areas in the literature}

Determining functional areas is highly diverse in terms of methodology and is most often related to the purpose of the research. Functional administrative areas in Poland include urban, rural and urban-rural communes (Heffner, 2015). Creating any classification based on spatial units will reveal various types of a functional, morphological or structural nature. The primary purpose is a systematising description that could be used for a cause-and-effect diagnosis of development processes. Issues of interpretation directly influenced the decision not to use IGiPZ PAN statistical research and analyses favouring the author's flexible classification. The divisions commonly used and recognised by the Central Statistical Office (GUS) are constructed according to rigid administrative criteria. The concepts developed in recent decades, however, are based on typologies of rural communes mainly developed by researchers such as W. Stola (1987), J. Bański (2014) and the functional urban typologies represented by K. Dziewoński (1962), P. Korcelli (1976), and P. Śleszyński $(2013,2016)$. The development of various typologies and classifications has also taken place in such research and development units as IRWiR PAN (Siemiński, 1979; Rosner, 1999; Heffner and Rosner, 2005; Stanny, 2013), and IGP UW (Swianiewicz, 1989; Śleszyński and Komornicki, 2016).

In Marburg in Germany, geographers considered a typology based on segmentation, demonstrating functionality in their work on tourism management in protected areas. As a marketing tool, it served those responsible for supervising tourism in geographically delimited areas under protection or special development (Bild, Opp, 2013). The spatial differentiation of rural areas and their development is dealt with by the economists I. Hodge (University of Cambridge) and P. Midmore (University of Aberystwyth). Based on experience from the UK, they proposed several models (local, territorial, sectoral) that describe the complex interactions and dependencies present in rural areas today (Hodge, 
Midmore, 2008). In Belgium, sustainable development issues, ecology, and spatial planning have been taken up by geographers from the University of Ghent. As part of the research, a graded and large-scale landscape typology considering supra-regional integration was developed (Van Eetvelde, Antrop, 2009).

A large-scale and multi-dimensional typology of urban centres was based on variable socio-economic, environmental and land use data by A. Krehl and S. Siedentop (2018). In turn, researchers from Salzburg identified existing urban structural types and proposed a new typology, paying particular attention to buildings' form and their external appearance (Lehner, Blaschke, 2019).

The location concept is based on an analysis of distance from centre to periphery (the urban-rural continuum principle). The most common criterion identifying a given type is measuring the travel time necessary for residents to reach the centre. This approach distinguishes cities and their zones of influence from traditional rural and peripheral areas. Location conditions play an essential role in the typology constructed by T. Komornicki and Śleszyński (2009), which considers functional connections and urban-rural relations (Bański, 2014).

Combinational typology is a complex form and is created by bringing together elements present in the structural and locational approaches. An example is a typology developed by Bański (2012) commissioned by the Ministry of Regional Development. It essentially refers to the functional types in KPZK 2030, and its research result is the identification of two types of rural area: those which play an active part in the development and those requiring support for such development (Bański, 2014).

\section{Methods of identifying the functional classification of the communes studied}

Structural typology makes it possible to group rural areas according to their socio-economic characteristics, and following from this, leading economic functions are essential and are assigned an appropriate functional type. This typology in Poland was developed in Stola's habilitation thesis (1987) and later modified by Bański and Stola (2002) by synthetically capturing the leading sectors of economic activity in the socio-economic structure of a given area. Their determination is based on a set of diagnostic features that describe various elements in a reference unit, including economic functions such as industry, trade, services, transport, tourism and recreation, agriculture, and forestry. Having a significant number of features theoretically allows several dozen functional types to be created, but only a few are considered (Bański, 2014).

In 2013, Śleszyński and Komornicki made a functional classification of Polish communes to monitor spatial planning using the deductive-inductive method by identifying detailed criteria on a local scale through a so-called functional typology. The research methodology for this study used a classification procedure consisting of selecting and establishing the hierarchy of the unit (commune), the selection of criteria appropriate for a given category of commune, assigning communes based on detailed criteria, and dividing (internal differentiation) of categories into subcategories (Śleszyński, Komornicki, 2016).

For this work, a critical role is played by the functional typology of communes developed by Bański in 2009 for the needs of the Ministry of Regional Development. It comprised ten standardised statistical measures characterising socio-economic development for 2002-2007. Bański's functional structure for communes (2010) distinguishes 
the following eight types: urban, urbanised, multifunctional transitional, highly agricultural, agriculture dominant, tourist and recreational, forest, mixed (Bański, 2014).

For research and analyses conducted in Świętokrzyskie Voivodeship, the relative criteria were referenced against characteristics from all 102 communes. The statistical data was homogeneous and covered 2010. The diagnostic features taken into account when constructing the functional structure considered the following criteria: social, financial, economic, spatial and infrastructural (Table 1).

Table 1. Diagnostic features used to determine the functional structure of communes

\begin{tabular}{|c|c|}
\hline Criterion & Diagnostic features \\
\hline \multirow{5}{*}{ social } & population density \\
\hline & birth rate \\
\hline & commune migration balance for permanent residents per 1000 population \\
\hline & proportion of registered unemployed in the working-age population \\
\hline & non-working age population per 100 working-age \\
\hline \multirow{6}{*}{$\begin{array}{l}\text { financial and } \\
\text { economic }\end{array}$} & revenue and expenditure balance per capita for communes and urban areas \\
\hline & $\begin{array}{l}\text { number of entities from the national economy in the REGON register per } 1000 \\
\text { working-age population }\end{array}$ \\
\hline & proportion of farms running agricultural activity out of all agricultural farms \\
\hline & proportion of farms producing mainly for the market \\
\hline & number of tourists staying in tourist accommodation \\
\hline & $\begin{array}{l}\text { the number of permanent patients in health resort treatment facilities to the } \\
\text { total population }\end{array}$ \\
\hline \multirow{7}{*}{$\begin{array}{l}\text { spatial and } \\
\text { infrastructural }\end{array}$} & number of dwellings per 1000 population \\
\hline & number of year-round bed places in collective tourist accommodation \\
\hline & number of fixed monuments \\
\hline & proportion of forests in the commune total \\
\hline & proportion of protected areas in the commune total \\
\hline & proportion of agricultural land in a commune to the total area \\
\hline & the proportion of orchards in the total agricultural land area \\
\hline
\end{tabular}

Source: author

The broad spectrum of the diagnostic features analysed results from the necessity to construct a reliable, functional structure of communes, which will be used later to assess the activities of local government in Świętokrzyskie Voivodeship considering environmental protection tasks.

Comparability within individual diagnostic features was possible through standardisation constructed according to the following scheme:

$$
\text { Stand }=\frac{\text { Wdcd }- \text { Wmincd }}{\text { Wmaxcd }- \text { Wmincd }} \times 100
$$

where:

Stand - standardisation reference for a given indicator

$\mathrm{W}_{\mathrm{dcd}}$ - value of a given diagnostic feature

$\mathrm{W}_{\text {mincd }}$ - value of the minimum diagnostic feature

$\mathrm{W}_{\text {maxcd }}$ - value of the maximum diagnostic feature 
The analysis of statistical material, including those for selected measures, made it possible to determine eight main functional types of commune. Each of the 102 local government units underwent an assessment to be allocated to a type using five diagnostic features, taking into account the need to choose them from all three types of criterion. The choice of diagnostic features was determined both substantively and statistically and partially determined the analysed area. The diagnostic features considered in the functional structure had to show high variability and have no correlation with other variables. Thus, features with low variability and those that could be potentially correlated with other variables and would provide similar information were eliminated.

Additionally, in most cases (the minimum for the first three indicators), specific necessary indicator scales for key diagnostic parameters were defined depending on a given functional type. The exceptions were the multifunctional areas designated finally, and all administrative units that did not meet any predefined criteria were classified into this group. Determining threshold values within a given functional type was possible thanks to the empirical distribution of the indicators.

The work here attempts to quantify individual types and make a qualitative assessment allowing the development of a hierarchy within types through a synthetic index. It took into account the key diagnostic features for a given functional structure and was calculated based on the following formula:

$$
\mathrm{W}_{\text {sum }}=\frac{\operatorname{Ref} 1 * r 1+\operatorname{Ref} 2 * r 0.8+\operatorname{Ref} 3 * r 0.6+\operatorname{Ref} 4 * r 0.4+\operatorname{Ref} 5 * r 0.2}{5}
$$

where:

$\mathrm{W}_{\text {sum }}$ - standardised sum

Stand $_{\mathrm{n}+1}-$ indicator size after standardisation

$r_{1-0.2}$ - ranking factor

The ranking factor was introduced to differentiate the importance of diagnostic features depending on the dominant factor in a given functional type. Its value ranged from 1 to 0.2 , at 0.2 intervals. The larger the number, the more critical the diagnostic feature in a given functional structure.

Analysis of the frequency of use of individual diagnostic features to construct a functional structure allows for a broader look at the qualitative use of the indicators (Table 2).

Determining the level of importance of a given indicator was possible because the ranking factor was included in the research. In this case, the sum of the ranks of the indicators used in the delimitation was then divided by the number of diagnostic features present. In the case of fractions, the number was rounded up to one decimal place. In this respect, the most important features were the number of permanent patients in health resort treatment establishments to the total population, the proportion of farms producing mainly for the market, population density, and the number of tourists staying in tourist accommodation establishments. It is worth noting that a high position was associated with a specialised feature with the lowest frequency of use. In the next stage of the analysis, the level of indicator usefulness was taken into account. The relationship was as follows: the more significant the frequency of using a given diagnostic feature, the higher the level of usefulness (closer to 1). 
Table 2. Analysis of the usefulness of the diagnostic features used to determine the functional structure of communes

\begin{tabular}{|c|c|c|c|c|}
\hline $\begin{array}{l}\text { Criterion } \\
\text { type }\end{array}$ & Diagnostic feature & $\begin{array}{l}\text { Frequency of } \\
\text { use and rank }\end{array}$ & $\begin{array}{l}\text { Importance } \\
\text { level of } \\
\text { indicator }\end{array}$ & $\begin{array}{l}\text { Usefulness } \\
\text { level of } \\
\text { indicator }\end{array}$ \\
\hline \multirow{5}{*}{ social } & population density & $\begin{array}{l}1 \mathrm{M}, 2 \mathrm{ZM} \\
\text { 3RN }\end{array}$ & 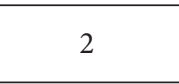 & 1 \\
\hline & birth rate & $4 \mathrm{RP}, 2 \mathrm{~W}$ & 3 & 2 \\
\hline & $\begin{array}{l}\text { commune migration balance } \\
\text { for permanent residents per } 1000 \\
\text { population }\end{array}$ & $\begin{array}{l}\text { 4M, 5TU, } \\
\quad 5 \mathrm{TR}\end{array}$ & 4.7 & 1 \\
\hline & $\begin{array}{l}\text { proportion of the registered } \\
\text { unemployed in the working-age } \\
\text { population }\end{array}$ & $5 \mathrm{RS}, 4 \mathrm{~W}$ & 4.5 & 2 \\
\hline & $\begin{array}{l}\text { non-working age population } \\
\text { per } 100 \text { working-age }\end{array}$ & $\begin{array}{l}\text { 4RS, 5RP, } \\
\text { 5RN }\end{array}$ & 4.7 & 1 \\
\hline \multirow{6}{*}{$\begin{array}{l}\text { financial and } \\
\text { economic }\end{array}$} & $\begin{array}{l}\text { revenue and expenditure balance } \\
\text { per capita for communes and } \\
\text { urban areas }\end{array}$ & $5 Z M, 1 W$ & 3 & 2 \\
\hline & $\begin{array}{l}\text { number of entities from the } \\
\text { national economy in the REGON } \\
\text { register per } 1000 \text { working-age } \\
\text { population }\end{array}$ & $\begin{array}{l}3 \mathrm{M}, 1 \mathrm{ZM} \text {, } \\
5 \mathrm{~W}\end{array}$ & 3 & 1 \\
\hline & $\begin{array}{l}\text { proportion of farms running } \\
\text { agricultural activity out of the total } \\
\text { number of farms }\end{array}$ & $3 R P, 2 R N$ & 2.5 & 2 \\
\hline & $\begin{array}{l}\text { proportion of farms producing } \\
\text { mainly for the market }\end{array}$ & 2RS, 1RP & 1.5 & 2 \\
\hline & $\begin{array}{l}\text { number of tourists staying } \\
\text { in tourist accommodation }\end{array}$ & 3TU, 1TR & 2 & 2 \\
\hline & $\begin{array}{l}\text { the number of permanent patients } \\
\text { in health resort treatment facilities } \\
\text { to the total population }\end{array}$ & $1 \mathrm{TU}$ & 1 & 3 \\
\hline \multirow{7}{*}{$\begin{array}{l}\text { spatial and } \\
\text { infrastructural }\end{array}$} & $\begin{array}{l}\text { number of dwellings per } 1000 \\
\text { population }\end{array}$ & $\begin{array}{c}2 \mathrm{M}, 4 \mathrm{ZM}, \\
3 \mathrm{~W}\end{array}$ & 3 & 1 \\
\hline & $\begin{array}{l}\text { number of year-round bed places } \\
\text { in collective tourist } \\
\text { accommodation establishments }\end{array}$ & 2TU, 3TR & 2.5 & 2 \\
\hline & number of fixed monuments & $5 \mathrm{M}, 2 \mathrm{TR}$ & 3.5 & 2 \\
\hline & $\begin{array}{l}\text { proportion of forest in the total } \\
\text { commune area }\end{array}$ & 4TU, 3RS & 3.5 & 2 \\
\hline & $\begin{array}{l}\text { proportion of protected areas in the } \\
\text { total commune area }\end{array}$ & $3 \mathrm{TR}$ & 1 & 3 \\
\hline & $\begin{array}{l}\text { proportion of agricultural land } \\
\text { in a commune to the total area }\end{array}$ & $\begin{array}{l}\text { 3ZM, 2RP, } \\
\text { 2RN }\end{array}$ & 2.3 & 1 \\
\hline & $\begin{array}{l}\text { the proportion of orchards in the } \\
\text { total agricultural land area }\end{array}$ & 1RS, 4RN & 2.5 & 2 \\
\hline
\end{tabular}

Source: author 
The most useful diagnostic features were population density, the balance of commune migration for permanent residents per 1000 population, non-working-age population per 100 working-age, number of entities of the national economy in the REGON register per 1000 working-age population, number of dwellings per 1000 population, and the proportion of agricultural land in the commune to its total area.

The ranking factor runs from highest to lowest. When classifying individual areas, the principle of exclusivity was applied, which meant that only a single type was assigned to a given commune. Thus, previously classified communes were not taken into account when classifying the following type, resulting in standardisation. The final value of this synthetic index was influenced by components of the actual scale of diagnostic features, expressed by standardisation to a reference scale from 0 to 100 . A higher index determined the achieved result in the functional structure. However, in some justified cases, the inverse of the index was used. It happened where a higher index did not positively indicate the existence of certain phenomena (e.g. unemployment) or a situation where the identified area could be characterised by an inverse relationship, e.g. low population density.

\section{Functional types of communes in Świętokrzyskie Voivodeship}

\section{Urban areas}

Communes classified as urban areas $(\mathrm{M})$ have the highest population density (over 700 per $\mathrm{km}^{2}$ ), the number of dwellings per 1000 population is 280 or more, and a relatively large (over 150) number of entities from the national economy on the REGON register per 1000 working-age population. In addition, these areas show a negative balance of commune migration for permanent residents per 1000 population, and the presence of fixed monuments in their area.

The use of specific diagnostic features made it possible to delimit the urban areas which included the largest cities in Świętokrzyskie Voivodeship with voivodeship and poviat rank: Kielce, Ostrowiec Świętokrzyski, Starachowice, Sandomierz, Skarżysko-Kamienna (Table 3).

Table 3. Urban areas

\begin{tabular}{|c|c|c|c|c|c|c|c|c|c|c|c|}
\hline 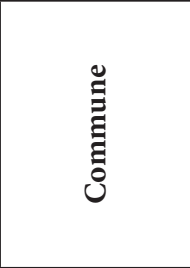 & 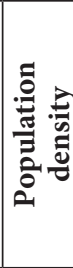 & 胥 & 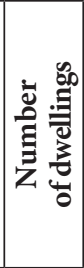 & 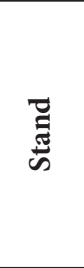 & 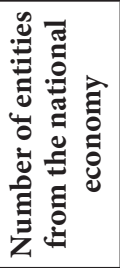 & 莡 & ن & 颉 & 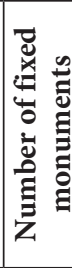 & 胥 & $\begin{array}{c}\Xi \\
\vdots \\
\sum_{3}^{\infty}\end{array}$ \\
\hline Kielce & 1846 & 100.00 & 287.7 & 31.48 & 216.1 & 96.9 & -5.5 & 77.92 & 88 & 100.00 & 218.46 \\
\hline Starachowice & 1650 & 89.21 & 350.5 & 58.98 & 151.0 & 59.9 & -3.9 & 71.25 & 6 & 6.82 & 201.10 \\
\hline $\begin{array}{l}\text { Ostrowiec } \\
\text { Świętokrzyski }\end{array}$ & 1591 & 85.97 & 315.3 & 43.56 & 172.2 & 71.9 & -4.5 & 73.75 & 7 & 7.95 & 193.80 \\
\hline Sandomierz & 870 & 46.29 & 333.1 & 51.36 & 221.7 & 100.0 & -7.7 & 87.08 & 58 & 65.91 & 184.86 \\
\hline $\begin{array}{l}\text { Skarżysko- } \\
\text {-Kamienna }\end{array}$ & 756 & 40.01 & 347.2 & 57.53 & 177.4 & 74.9 & -5.5 & 77.92 & 1 & 1.14 & 162.19 \\
\hline
\end{tabular}

Source: author based on GUS data 
Communes classified as this type show high urbanisation and industrialisation, as evidenced by the dense transport infrastructure and building levels. Thus, urban areas show the absence of such features as agricultural land and protected areas.

\section{Diversified urban areas}

In classifying diversified urban areas, relatively high indicators were of great importance, such as the number of entities from the national economy in the REGON register per 1000 working-age population (over 100). Additionally, other features turned out to be important: population density (over 100 per $\mathrm{km}^{2}$ ) and the number of dwellings per 1000 population (over 290).

In communes classified as this type, the proportion of agricultural land to the total area was lower than $40 \%$, and the balance of income and expenditure per capita of communes and urban areas was negative. It was assumed that urban areas delimited above would not undergo further classification.

The diversified urban areas included the following seven administrative units: Suchedniów, Sitkówka-Nowiny, Końskie, Miedziana Góra, Zagnańsk, Masłów and Morawica (Table 4).

Table 4. Diversified urban areas

\begin{tabular}{|c|c|c|c|c|c|c|c|c|c|c|c|}
\hline 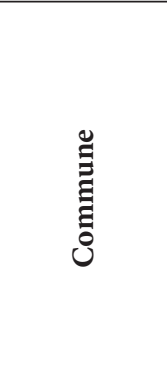 & 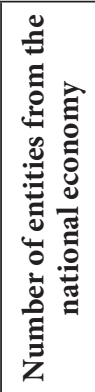 & $\begin{array}{l}\text { D } \\
\text { ڤ્ }\end{array}$ & 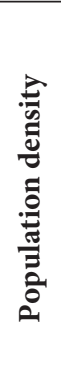 & $\begin{array}{l}\vec{E} \\
\text { W }\end{array}$ & 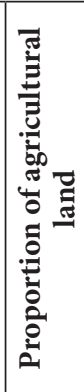 & 节 & 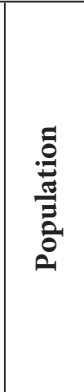 & تే & 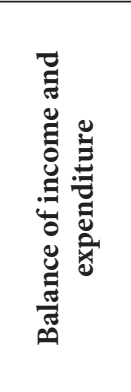 & E્ & $\begin{array}{l}\vdots \\
\vdots \\
3 \\
3\end{array}$ \\
\hline Suchedniów & 146.6 & 87.0 & 144 & 85.82 & 3.67 & 100.00 & 360.3 & 63.27 & -582.35 & \begin{tabular}{|l|l|}
61.99 \\
\end{tabular} & 243.49 \\
\hline $\begin{array}{l}\text { Sitkówka- } \\
\text { Nowiny }\end{array}$ & 138.7 & 80.3 & 163 & 100.00 & 19.60 & 87.30 & 338.9 & 53.90 & -826.34 & 71.73 & 237.06 \\
\hline Końskie & 148.4 & 88.6 & 148 & 88.81 & 24.04 & 83.76 & 290.4 & 32.66 & -477.14 & 57.78 & 225.32 \\
\hline $\begin{array}{l}\text { Miedziana } \\
\text { Góra }\end{array}$ & 136.8 & 78.7 & 150 & 90.30 & 33.08 & 76.56 & 306.6 & 39.75 & -526.97 & 59.77 & 215.13 \\
\hline Zagnańsk & 116.6 & 61.2 & 103 & 55.22 & 16.54 & 89.74 & 404.4 & 82.57 & -734.13 & 68.05 & 195.01 \\
\hline Masłów & 131.9 & 74.4 & 121 & 68.66 & 28.60 & 80.13 & 302.4 & 37.92 & -448.16 & 56.63 & 194.86 \\
\hline Morawica & 129.4 & 72.3 & 104 & 55.97 & 33.89 & 75.91 & 307.0 & 39.93 & -1030.01 & 79.87 & 181.78 \\
\hline
\end{tabular}

Source: author based on GUS data

The communes in this group are diversified in size, ranging from $46 \mathrm{~km}^{2}$ (Sitkówka-Nowiny) to $250 \mathrm{~km}^{2}$ (Końskie). Thus, the largest population is in Końskie commune (37 109 inhabitants), and the lowest in Sitkówka-Nowiny commune (7420 inhabitants). In other communes, numbers range from 10324 to 14634 inhabitants. Diverse urban areas are a transitional form between urbanised (urban) and rural areas. 


\section{Tourist and spa areas}

When delimiting tourist and spa areas, it was necessary to consider a specific diagnostic feature, the number of patients in spa treatment facilities, and the total population (a limit of at least 1000 was adopted). Additionally, this was confirmed by year-round accommodation in collective tourist accommodation establishments (over 400); the number of tourists staying in tourist accommodation establishments (over 10000 ); the proportion of forest in the total area of the commune (minimum level of 30\%) and a positive balance of commune migration for permanent residents per 1000 population.

The administrative units classified into this group are Busko-Zdrój and Solec-Zdrój (Table 5). In Świętokrzyskie Voivodeship, curative waters (chloride, sulphide and iodine) are used in spas located in these communes. In addition, belonging to this group may be evidenced by the special status of spa communes, which function in Poland under the Act of 28 July 2005 on spa treatment, health resorts and spa protection areas, and spa communes (Journal of Laws of 2016, item 879).

Table 5. Tourist and spa areas

\begin{tabular}{|c|c|c|c|c|c|c|c|c|c|c|c|}
\hline $\begin{array}{l}\text { 音 } \\
\text { 苛 }\end{array}$ & 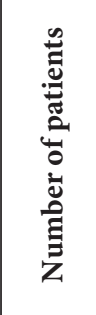 & $\tilde{\Xi}$ & 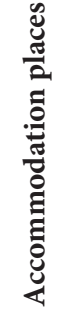 & 菾 & 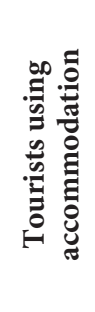 & 莣 & 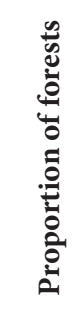 & 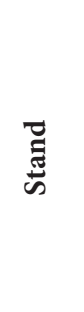 & 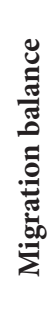 & 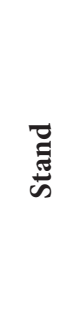 & $\begin{array}{l}\Xi \\
\vdots \\
3\end{array}$ \\
\hline $\begin{array}{l}\text { Busko- } \\
\text {-Zdrój }\end{array}$ & 34085 & 100.00 & 1387 & 100 & 33313 & 100 & 38.60 & 54.37 & 0.5 & 71.52 & 264.61 \\
\hline $\begin{array}{l}\text { Solec- } \\
\text {-Zdrój }\end{array}$ & 2193 & 6.43 & 490 & 35 & 11685 & 35 & 30.60 & 43.10 & 2.3 & 82.91 & 76.30 \\
\hline
\end{tabular}

Source: author based on GUS data

Spa treatment has an essential impact on the economy of Świętokrzyskie Voivodeship, as evidenced by qualifying health tourism and the sub-area of spa tourism to the intelligent specialisation of Świętokrzyskie Voivodeship. There are 11 sanatoriums with 1491 beds in the voivodeship and three spa hospitals with 534 beds ( $7^{\text {th }}$ highest in Poland) (Bubula et al., 2011).

\section{Tourism and recreation areas}

Administrative units classified as tourism and recreational areas (TR) should have several features in terms of infrastructure and historical and natural conditions.

For this group, the following diagnostic features were taken into account: the number of tourists staying in tourist accommodation establishments (over 4000 people); the number of fixed monuments ( 3 or more); the number of year-round bed places in collective tourist accommodation establishments (over 150); a minimum of $85 \%$ protected areas in 
the commune total and the balance of commune migration for permanent residents per 1000 population.

The following communes are classified as tourist and recreational areas: Chęciny, Górno, Pińczów, Bodzentyn, Szydłów, Nowa Słupia and Bodzechów (Table 6). It is worth adding that within these administrative units there are the greatest tourist attractions of Świętokrzyskie Voivodeship which include the Royal Castle in Chęciny, Cedzyna Reservoir, the Amusement and Miniature Park "Sabat Krajno", Łysica and Łysa summits, Holy Cross Basilica, Krzemionki Opatowskie, the ruins of the 14th century royal castle in Szydłów, Świętokrzyska Narrow-Gauge Railway “Ciuchcia Ekspres Ponidzie”.

Table 6. Tourism and recreation areas

\begin{tabular}{|c|c|c|c|c|c|c|c|c|c|c|c|}
\hline 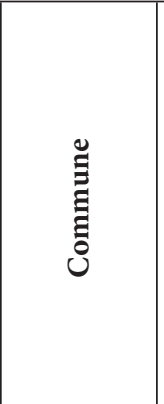 & 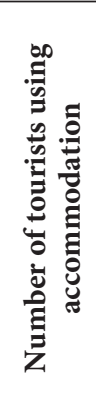 & & 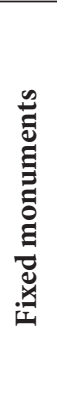 & 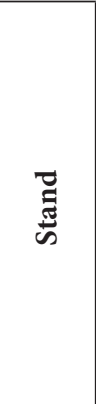 & 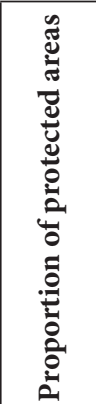 & $\begin{array}{l}\vec{\Xi} \\
\text { 今 }\end{array}$ & 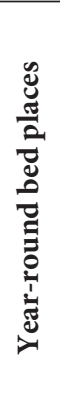 & $\begin{array}{l}\vec{E} \\
\text { E⿱艹 }\end{array}$ & 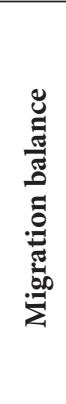 & 芯 & 莕 \\
\hline Chęciny & 14401 & 78 & 45 & 100.00 & 89.07 & 82.55 & 268 & 72 & 2.2 & 82.28 & 239.31 \\
\hline Górno & 18578 & 100 & 4 & \begin{tabular}{|l|}
8.89 \\
\end{tabular} & 100.16 & 92.82 & 370 & 100 & 4.7 & 98.10 & 206.73 \\
\hline Pińczów & 5032 & 27 & 22 & 48.89 & 99.97 & 92.65 & 235 & 64 & -4.1 & 42.41 & 148.89 \\
\hline Bodzentyn & 4519 & 24 & 13 & 28.89 & 100.91 & 93.52 & 233 & 63 & -0.5 & 65.19 & 131.34 \\
\hline Szydłów & 6173 & 33 & 12 & 26.67 & 99.66 & 92.36 & 156 & 42 & -1.2 & 60.76 & 129.27 \\
\hline $\begin{array}{l}\text { Nowa } \\
\text { Słupia }\end{array}$ & 6956 & 37 & 5 & 11.11 & 103.39 & 95.82 & 189 & 51 & -2.4 & 53.16 & 126.38 \\
\hline Bodzechów & 5263 & 28 & 3 & 6.67 & 99.70 & 92.40 & 155 & 42 & 1.4 & 77.22 & 108.95 \\
\hline
\end{tabular}

Source: author based on GUS data

Tourism is perceived in the voivodeship as one of the essential branches of the economy due to strong linkages to other sectors and areas of life such as culture. The implementation of the tourism development strategy for 2007-2013 contributed to significant changes resulting in the development of the product, marketing and investment offer. The development of tourism in Świętokrzyskie Voivodeship consists of many factors, including afforestation (Świętokrzyski National Park), geology (Świętokrzyskie Mountains, fossil marine and land environments), and history (archaeological and iron-working sites). All these elements create natural and cultural value demonstrating the high attractiveness of the region (Baran et al., 2015).

\section{Agriculture and horticultural areas}

The following factors were taken into account when classifying agricultural and horticultural areas (RS): the proportion of orchards in the total agricultural area (over 40\%); 
the proportion of farms producing mainly for the market (above 15\%); and the proportion of forests in the total area of the commune (at a level of at least 25\%). Additionally, social aspects were considered: non-working-age population per 100 working-age (over 60 ) and the proportion of registered unemployed in the working-age population (below $10 \%)$.

In Świętokrzyskie Voivodeship, several communes have been classified as agricultural and horticultural in the eastern part of the voivodeship: Obrazów, Samborzec, Koprzywnica and Łoniów (Table 7). Fruit growing is a branch of agricultural production that is undergoing intensive changes today due to technological progress in the field of fruit production and storage (Traczyk, Wójcik, 2016).

Table 7. Agriculture and horticultural areas

\begin{tabular}{|c|c|c|c|c|c|c|c|c|c|c|c|}
\hline 泀 & 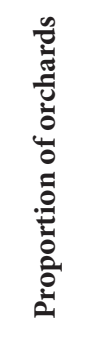 & 墕 & 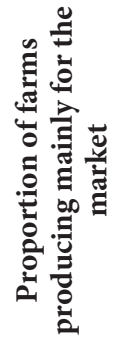 & 节 & 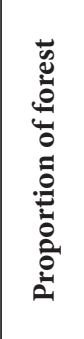 & 预 & 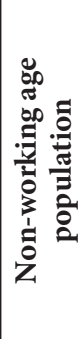 & 荀 & 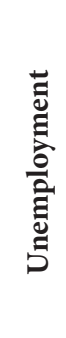 & 题 & $\begin{array}{l}\Xi \\
\vdots \\
3\end{array}$ \\
\hline Obrazów & 80.27 & 100.00 & 54.40 & 77.1 & 12.20 & 82.82 & 64.50 & 79.15 & 7.12 & 84.46 & 246.38 \\
\hline Samborzec & 64.65 & 80.54 & 53.86 & 76.3 & 15.30 & 78.45 & 61.00 & 65.64 & 7.68 & 81.11 & 218.15 \\
\hline Koprzywnica & 48.93 & 60.96 & 24.88 & 35.0 & 24.40 & 65.63 & 61.00 & 65.64 & 8.96 & 73.42 & 157.54 \\
\hline Łoniów & \begin{tabular}{|l|}
40.27 \\
\end{tabular} & 50.17 & 16.35 & 22.9 & 3.90 & 94.51 & 61.50 & 67.57 & 7.93 & 79.61 & 155.38 \\
\hline
\end{tabular}

Source: author based on GUS data

\section{Agricultural production areas}

Agricultural production areas (RP) showed the following features: the proportion of farms producing mainly for the market (over $40 \%$ ); proportion of agricultural land area to the total area of the commune (over $40 \%$ ); the proportion of farms running agricultural activity in the total number of farms (over 40\%); negative population growth and nonworking-age population per 100 working-age. Agricultural production areas covered 22 communes (Table 8).

In 2010, there were changes in the land use on farms related to intensified modernisation and specialisation. The development of agriculture, and thus the occurrence of farms producing for the market, depends mainly on the soil quality. In this respect, Swiętokrzyskie Voivodeship is above the national average. Spatially, there is an evident polarisation between the south-eastern part of the voivodeship (soil valuation classes I-III) and the north-western part (soil valuation classes IV-VI) (Bielewicz-Kosińska, 2012). 
Table 8. Agricultural production areas

\begin{tabular}{|c|c|c|c|c|c|c|c|c|c|c|c|}
\hline 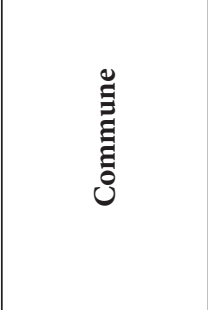 & 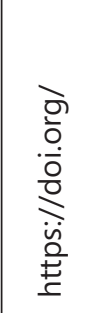 & 莡 & 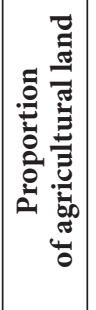 & ت્ّ & 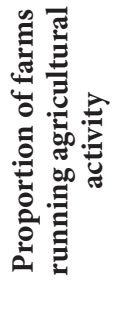 & 题 & 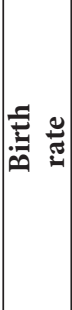 & 矛 & 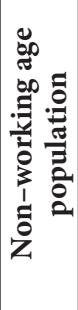 & 芯 & $\begin{array}{l}\Xi \\
\vdots \\
\vdots \\
3\end{array}$ \\
\hline Działoszyce & 70.51 & 100.00 & 58.90 & 69.87 & 70.51 & 100.00 & -46 & 85.23 & 69.1 & 96.91 & 253.86 \\
\hline Skalbmierz & 60.61 & 85.9 & 81.80 & 100 & 60.61 & 85.91 & -31 & 75.17 & \begin{tabular}{|l|}
64.2 \\
\end{tabular} & 77.99 & 250.64 \\
\hline Czarnocin & 57.40 & 81.3 & 77.05 & 93.75 & 57.40 & 81.33 & -29 & 73.83 & \begin{tabular}{|l|}
65.1 \\
\end{tabular} & 81.47 & 237.92 \\
\hline Sadowie & 54.99 & 77.9 & 79.50 & 96.98 & 54.99 & 77.90 & -17 & 65.77 & 63 & 73.36 & 231.47 \\
\hline Złota & 59.60 & 84.5 & 65.13 & 78.06 & 59.60 & 84.48 & -32 & 75.84 & 63.3 & 74.52 & 230.93 \\
\hline Opatowiec & 53.41 & 75.7 & 68.26 & 82.18 & 53.41 & 75.66 & -27 & 72.48 & 62 & 69.50 & 218.58 \\
\hline Bejsce & 48.50 & 68.7 & 70.22 & 84.76 & 48.50 & 68.67 & -46 & 85.23 & 62.4 & 71.04 & 214.61 \\
\hline $\begin{array}{l}\text { Kazimierza } \\
\text { Wielka }\end{array}$ & 42.29 & 59.8 & 76.83 & 93.47 & 42.29 & 59.83 & -68 & 100.00 & 56.6 & 48.65 & 212.44 \\
\hline Wojciechowice & 51.89 & 73.5 & 67.13 & 80.70 & 51.89 & 73.50 & -14 & 63.76 & 64.0 & 77.22 & 210.74 \\
\hline Lipnik & 49.00 & 69.4 & 70.03 & 84.51 & 49.00 & 69.38 & -24 & 70.47 & 60.9 & 65.25 & 209.42 \\
\hline Nowy Korczyn & 49.68 & 70.4 & 62.05 & 74.01 & 49.68 & 70.35 & -33 & 76.51 & 65.1 & 81.47 & 205.63 \\
\hline Pacanów & 44.23 & 62.6 & 68.16 & 82.05 & 44.23 & 62.59 & -48 & 86.58 & 69.6 & 98.84 & 204.37 \\
\hline Wilczyce & 51.86 & 73.5 & 59.37 & 70.49 & 51.86 & 73.46 & -23 & 69.80 & 59.9 & 61.39 & 204.30 \\
\hline Michałów & 48.46 & 68.6 & 63.63 & 76.09 & 48.46 & 68.62 & -29 & 73.83 & 68.3 & 93.82 & 203.94 \\
\hline Wodzisław & 48.46 & 68.6 & 67.48 & 81.16 & 48.46 & 68.61 & -14 & 63.76 & \begin{tabular}{|l|}
65.2 \\
\end{tabular} & 81.85 & 203.48 \\
\hline Waśniów & 47.28 & 66.9 & 69.40 & 83.68 & 47.28 & 66.93 & -5 & 57.72 & \begin{tabular}{|l|}
64 \\
\end{tabular} & 77.22 & 200.21 \\
\hline Baćkowice & 50.05 & 70.9 & 62.64 & 74.80 & 50.05 & 70.88 & -9 & 60.40 & 61.2 & 66.41 & 200.06 \\
\hline Wiślica & 46.78 & 66.2 & 63.33 & 75.69 & 46.78 & 66.21 & -32 & 75.84 & 61.4 & 67.18 & 199.52 \\
\hline Imielno & 47.14 & 66.7 & 63.20 & 75.53 & 47.14 & 66.73 & -10 & 61.07 & 66.5 & 86.87 & 195.09 \\
\hline $\begin{array}{l}\text { Słupia } \\
\text { (Jędrzejowska) }\end{array}$ & 45.09 & 63.8 & 66.03 & 79.25 & 45.09 & 63.81 & -9 & 60.40 & 67.8 & 91.89 & 193.33 \\
\hline $\begin{array}{l}\text { Słupia } \\
\text { (Konecka) }\end{array}$ & 50.34 & 71.3 & 44.51 & 50.93 & 50.34 & 71.28 & -7 & 59.06 & 66 & 84.94 & 181.82 \\
\hline Moskorzew & 40.77 & 57.7 & 53.35 & 62.57 & 40.77 & 57.66 & -14 & 63.76 & 65.6 & 83.40 & 171.16 \\
\hline
\end{tabular}

Source: author based on GUS data

\section{Semi-subsistence areas}

The following features determined classification as semi-subsistent smallholdings areas $(\mathrm{RN})$ : the proportion of agricultural land in the commune to the total area (more than $30 \%$ ); the proportion of farms running agricultural activity in the total number of farms (over 80\%); population density (less than 100); the proportion of orchards in the total agricultural area and the number of non-working age population per 100 working-age. Thirty communes were classified as semi-subsistent smallholdings areas (Table 9). 
Table 9. Semi-subsistence areas

\begin{tabular}{|c|c|c|c|c|c|c|c|c|c|c|c|}
\hline 泀 & 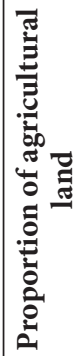 & 节 & 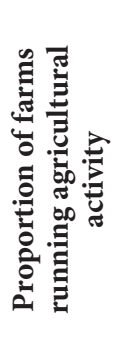 & 节 & 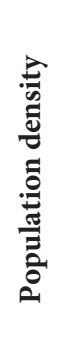 & 节 & 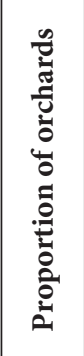 & 馬 & 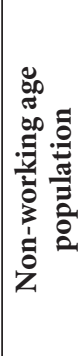 & 节 & $\begin{array}{l}\Xi \\
3 \\
3 \\
3\end{array}$ \\
\hline Zawichost & 53.26 & 66.68 & 90.83 & 89.1 & 59 & 77.27 & 27.68 & 92.67 & 63.9 & 76.83 & 224.47 \\
\hline Stopnica & 59.84 & 75.93 & 99.00 & 99.3 & 63 & 74.24 & 11.58 & 38.77 & 61.4 & 67.18 & 218.14 \\
\hline Klimontów & 65.00 & 83.17 & 93.44 & 92.4 & 86 & 56.82 & 13.61 & 45.57 & 64.2 & 77.99 & 212.51 \\
\hline Łubnice & 60.65 & 77.06 & 99.47 & 99.9 & 52 & 82.58 & 1.08 & 3.61 & 69.9 & 100 & 211.99 \\
\hline Oksa & 58.93 & 74.64 & 98.47 & 98.7 & 53 & 81.82 & 0.15 & 0.50 & 67 & 88.80 & 206.42 \\
\hline Gnojno & 55.21 & 69.41 & 93.10 & 92.0 & 48 & 85.61 & 4.97 & 16.62 & 67.5 & 90.73 & 204.62 \\
\hline Tarłów & 38.76 & 46.31 & 97.67 & 97.7 & 34 & 96.21 & 14.10 & 47.21 & 66.5 & 86.87 & 204.53 \\
\hline Nagłowice & 51.35 & 63.99 & 99.53 & 100 & 45 & 87.88 & 0.37 & 1.22 & 67.9 & 92.28 & 200.90 \\
\hline Ożarów & 50.43 & 62.70 & 92.12 & 90.7 & 62 & 75.00 & 9.64 & 32.27 & 54.1 & 39.00 & 194.74 \\
\hline Iwaniska & 53.55 & 67.08 & 98.35 & 98.5 & 67 & 71.21 & 1.98 & 6.62 & 62.1 & 69.88 & 194.07 \\
\hline Tuczępy & 41.83 & 50.62 & 98.62 & 98.9 & 46 & 87.12 & 4.06 & 13.59 & 68.3 & 93.82 & 191.17 \\
\hline Kije & 43.45 & 52.89 & 99.32 & 99.7 & 45 & 87.88 & 1.22 & 4.08 & 65.4 & 82.63 & 190.34 \\
\hline Łagów & 50.27 & 62.47 & 91.60 & 90.1 & 62 & 75.00 & 2.76 & 9.23 & 63.5 & 75.29 & 186.23 \\
\hline Sobków & 48.19 & 59.56 & 93.19 & 92.1 & 58 & 78.03 & 0.62 & 2.07 & 58.4 & 55.60 & 183.07 \\
\hline Pierzchnica & 40.22 & 48.35 & 92.15 & 90.8 & 46 & 87.12 & 4.44 & 14.87 & 65.1 & 81.47 & 182.44 \\
\hline Radków & 33.62 & 39.08 & 96.84 & 96.6 & 29 & 100 & 0.78 & 2.60 & 66.9 & 88.42 & 180.96 \\
\hline Łopuszno & 42.60 & 51.70 & 90.76 & 89.0 & 51 & 83.33 & 0.33 & 1.11 & 60 & 61.78 & 175.82 \\
\hline Kluczewsko & 38.49 & 45.92 & 89.33 & 87.2 & 39 & 92.42 & 0.55 & 1.84 & 65.6 & 83.40 & 175.23 \\
\hline Bałtów & 33.14 & 38.41 & 88.02 & 85.6 & 36 & 94.70 & 3.70 & 12.40 & 64.7 & 79.92 & 171.85 \\
\hline Bogoria & 45.75 & 56.12 & 81.57 & 77.5 & 65 & 72.73 & 3.63 & 12.15 & 65.9 & 84.56 & 170.00 \\
\hline Małogoszcz & 45.42 & 55.66 & 92.31 & 91.0 & 81 & 60.61 & 0.47 & 1.56 & 56.8 & 49.42 & 167.40 \\
\hline Sędziszów & 51.87 & 64.72 & 86.64 & 83.9 & 89 & 54.55 & 0.83 & 2.79 & 54.3 & 39.77 & 167.25 \\
\hline Osiek & 37.70 & 44.82 & 85.54 & 82.5 & 61 & 75.76 & 4.70 & 15.72 & 64.4 & 78.76 & 165.70 \\
\hline Oleśnica & 47.15 & 58.09 & 83.10 & 79.4 & 74 & 65.91 & 0.87 & 2.93 & 63.2 & 74.13 & 165.32 \\
\hline Włoszczowa & 42.94 & 52.18 & 89.12 & 87.0 & 80 & 61.36 & 1.10 & 3.67 & 56.9 & 49.81 & 162.02 \\
\hline Krasocin & 36.95 & 43.75 & 85.23 & 82.1 & 56 & 79.55 & 0.39 & 1.32 & 61.1 & 66.02 & 160.33 \\
\hline Chmielnik & 37.99 & 45.22 & 88.95 & 86.8 & 81 & 60.61 & 4.22 & 14.13 & 59.6 & 60.23 & 159.05 \\
\hline Mirzec & 40.03 & 48.09 & 86.77 & 84.0 & 76 & 64.39 & 1.21 & 4.06 & 61.9 & 69.11 & 158.33 \\
\hline Radoszyce & 39.02 & 46.67 & 80.94 & 76.7 & 63 & 74.24 & 0.33 & 1.11 & 58.8 & 57.14 & 155.32 \\
\hline Mniów & \begin{tabular}{|l|}
49.32 \\
\end{tabular} & 61.14 & 81.04 & 76.8 & 99 & 46.97 & 0.36 & 1.21 & 57 & 50.19 & 153.28 \\
\hline
\end{tabular}

Source: author based on GUS data

According to the 2010 agricultural census, the number of farms in Swiętokrzyskie Voivodeship was 141 900, almost all in the private sector. Out of 103100 farms with over one ha of agricultural land, practically 100\% were independent. In 2010 the 
Table 10. Multifunctional areas

\begin{tabular}{|c|c|c|c|c|c|c|c|c|c|c|c|}
\hline 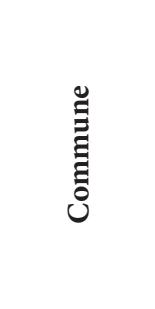 & 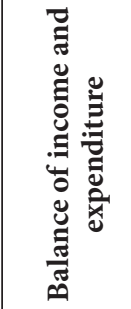 & 节 & 苞 & 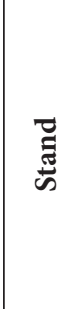 & 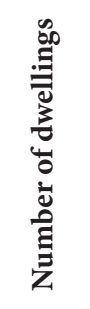 & تే & 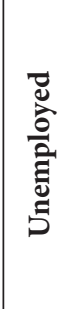 & ت्ञ & 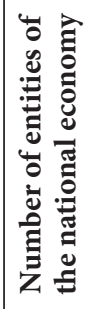 & تే & 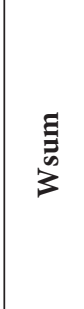 \\
\hline Staszów & -260.88 & 72.17 & 7 & 48.61 & 352.6 & 87.31 & 7.7 & 98.3 & 147.7 & 100.0 & 81.27 \\
\hline Połaniec & -585.99 & 53.74 & 74 & 95.14 & 322.7 & 64.86 & 7.4 & 100.0 & 102.1 & 45.4 & 71.84 \\
\hline Daleszyce & -149.97 & 78.45 & 81 & 100 & 274.8 & 28.90 & 10.2 & 79.6 & 117.2 & 63.5 & 70.09 \\
\hline Piekoszów & -131.35 & 79.51 & 52 & 79.86 & 319.3 & 62.31 & 9.8 & 83.2 & 98.0 & 40.5 & 69.08 \\
\hline Jędrzejów & -182.26 & 76.62 & 8 & 49.31 & 287.0 & 38.06 & 9.2 & 87.2 & 135.3 & 85.2 & 67.28 \\
\hline Raków & 28.23 & 88.56 & -12 & 35.42 & 324.5 & 66.22 & 11.8 & 68.3 & 98.2 & 40.7 & 59.85 \\
\hline Strawczyn & -1533.87 & 0.00 & 42 & 72.92 & 355.7 & 89.64 & 8.2 & 94.6 & 95.2 & 37.2 & 58.86 \\
\hline Opatów & -252.11 & 72.66 & -48 & 10.42 & 313.8 & 58.18 & 12.6 & 62.5 & 138.5 & 89.0 & 58.54 \\
\hline Rytwiany & -521.95 & 57.37 & -18 & 31.25 & 329.3 & 69.82 & 8.9 & 89.7 & 100.4 & 43.4 & 58.30 \\
\hline Smyków & -781.87 & 42.63 & 14 & 53.47 & 347.6 & 83.56 & 13.5 & 56.1 & 109.7 & 54.6 & 58.07 \\
\hline Wąchock & -531.69 & 56.81 & -33 & 20.83 & 369.5 & 100.00 & 12.9 & 60.5 & 106.5 & 50.7 & 57.75 \\
\hline Pawłów & -720.29 & 46.12 & 21 & 58.33 & 319.2 & 62.24 & 10.2 & 79.6 & 79.8 & 18.7 & 53.00 \\
\hline Bieliny & -515.12 & 57.75 & 62 & 86.81 & 236.3 & 0.00 & 9.3 & 86.8 & 87.1 & 27.4 & 51.76 \\
\hline Stąporków & -344.49 & 67.43 & -46 & 11.81 & 353.2 & 87.76 & 15.5 & 41.4 & 106.0 & 50.1 & 51.68 \\
\hline $\begin{array}{l}\text { Skarżysko } \\
\text { Kościelne }\end{array}$ & -651.53 & 50.02 & -5 & 40.28 & 347 & 83.11 & 17.6 & 26.4 & 90.7 & 31.7 & 46.30 \\
\hline Brody & 230.11 & 100.00 & -24 & 27.08 & 257.2 & 15.69 & 13.5 & 56.0 & 88.0 & 28.5 & \begin{tabular}{|l}
45.47 \\
\end{tabular} \\
\hline Łączna & -190.81 & 76.14 & -21 & 29.17 & 297.9 & 46.25 & 14.4 & 49.3 & 85.3 & 25.4 & 45.24 \\
\hline Secemin & -617.38 & 51.96 & -36 & 18.75 & 334.8 & 73.95 & 11.5 & 70.7 & 71.1 & 8.3 & 44.71 \\
\hline Fałków & -237.27 & 73.50 & -13 & 34.72 & 282.3 & 34.53 & 11.5 & 70.4 & 64.2 & 0.0 & 42.64 \\
\hline Gowarczów & -499.70 & 58.63 & -10 & 36.81 & 284.6 & 36.26 & 15.4 & 42.0 & 86.5 & 26.8 & 40.08 \\
\hline Dwikozy & -731.67 & 45.48 & -44 & 13.19 & 275.7 & 29.58 & 9.1 & 87.8 & 83.5 & 23.1 & 39.82 \\
\hline Ćmielów & -273.45 & 71.45 & -63 & 0.00 & 273.6 & 28.00 & 13.6 & 55.3 & 100.6 & 43.7 & 39.68 \\
\hline Kunów & -634.49 & 50.99 & -34 & 20.14 & 295.5 & 44.44 & 14.4 & 49.6 & 90.5 & 31.5 & 39.34 \\
\hline $\begin{array}{l}\text { Ruda } \\
\text { Maleniecka }\end{array}$ & -1000 & 30.27 & -35 & 19.44 & 325.6 & 67.04 & 15.4 & 42.3 & 83.2 & 22.8 & 36.38 \\
\hline Bliżyn & -231.58 & 73.83 & -10 & 36.81 & 249.6 & 9.98 & 21.2 & 0.0 & 97.1 & 39.5 & 32.02 \\
\hline
\end{tabular}

Source: author based on GUS data

average area of agricultural land per farm was $3.88 \mathrm{ha}$, but in recent years, the number of farms has been decreasing, which applies especially to the smallest, which should be considered favourable from an economic perspective. The smallest farms (up to one ha) accounted for $16.5 \%$ of all farms but used only $1.8 \%$ of the total agricultural area (Bielewicz-Kosińska, 2012). 


\section{Multifunctional areas}

When establishing the hierarchy of multifunctional areas, the following types of diagnostic feature were taken into account: revenue and expenditure balance per capita for communes and urban areas; birth rate; the number of dwellings per 1000 population; the proportion of registered unemployed in the working-age population; the number of entities from the national economy on the REGON register per 1000 working-age population. Multifunctional areas included 25 communes (Table 10).

Classification as a multifunctional area showed that these communes have varying functions without any clearly defined specialisation. A significant variation in the diagnosed social, financial, and economic features is noticeable within these areas, similar to spatial and infrastructural features. Mixed functions are because this group consists of those areas that meet none of the previously mentioned criteria.

\section{Conclusions}

In research, it is imperative to strive for the most precise understanding of a specific process's complexity, its functioning, and how it influences local and regional self-government. Developing empirically verified theoretical concepts that comprehensively capture the functioning and development of economic conditions seems to be necessary (Zioło, 2016).

The decision to select indicators identifying the functional structure of communes was based on several elementary assumptions. First of all, they must represent a broad spectrum of socio-economic factors equally. The indicators should be based on statistical data available at the commune level, and the availability of the data itself should enable an analysis of phenomena at similar time intervals. Adopting spatial aggregation at the commune level is essential for application reasons, as it is the lowest level of administrative division in which regional development policy is implemented. In addition, a commune is the smallest unit for which databases are widely available that enable a selection of indicators that satisfactorily describe the socio-economic characteristics of a given area (Mazur et al., 2015). It is possible to obtain the minimum statistical information set useful in delimitation (Śleszyński, 2013).

When trying to designate functional areas, methodological assumptions are fundamental, and significant roles are played by objectivity and the repeatability of a procedure. The relativism adopted in the classification criteria determines the universality of the method over a more extended time (Mazur et al., 2015). Bański (2014) indicates a few fundamental disadvantages when drawing up this typology, including arbitrariness in the selection of diagnostic features and class intervals for individual statistical measures; relying on subject-limited statistical analysis that is usually not comparable over the same period; subjectivism in the selection of indicators determining socio-economic structure (Bański, 2014). These imperfections in the new functional typology drawn up here have been minimised or even eliminated through the use of a large number of statistical measures (17), characterised by a lack of significant correlation with each other and by the use of time and spatially homogeneous statistical material covering data for all 102 communes of Świętokrzyskie Voivodeship in 2010. The delimitation of the designated functional areas in Świętokrzyskie Voivodeship considered social, financial and economic, and spatial and infrastructural criteria. 
The advantage of a typology based on an analysis of functional structure compared to the location approach results from the practical possibilities of formulating and analysing phenomena and processes within such territorial units as communes. In the functional approach, it is possible to indicate the dominant sectors of economic activity synthetically in a given commune by utilising diagnostic features (Bański, 2014).

The fundamental problem in developing the delimitation lies in the methodology, as there is no universal method that could unequivocally produce comparability. Due to the historically formed and diversified socio-economic position and size of a given commune, additional critical assumptions regarding delimitation concerning ease of interpretation, usefulness and flexibility were included (Śleszyński, 2013). Among the many researchers dealing with typology, many demonstrate the need for further work. M. Mazur, Bański, K. Czapiewski, Śleszyński (2015), in a publication devoted to an attempt at methodical delineation of rural areas and boundaries, indicated that "current classifications do not exhaust the complexity of the characteristics of rural areas and their modification and extension are proposed". The delimitation presented in this article is a new look at identifying specific areas in terms of economic or socio-economic features in Świętokrzyskie Voivodeship. The methodological assumptions adopted are objective and characterised by repetition of the procedure, which means they can be used when classifying communes in other voivodeships.

\section{References}

Bański, J. (2014). Współczesne typologie obszarów wiejskich w Polsce - przegląd podejść metodologicznych. Przegląd Geograficzny, 86(4), 441-470.

Baran, E., Kiniorska, I., Noga, M. (2015). Rozwój funkcji turystycznej obszarów wiejskich województwa świętokrzyskiego. Studia Komitetu Przestrzennego Zagospodarowania Kraju, 163, 252-266.

Bielewicz-Kosińska, B. (2012). Charakterystyka gospodarstw rolnych w województwie świętokrzyskim. Powszechny Spis Rolny 2010. Kielce: Zakład Wydawnictw Statystycznych.

Bild, Ch., Opp, Ch. (2013). Tourist typology research in protected areas. 5th Symposium for Research in Protected Areas, Conference Volume, 53-56.

Bubula, B., Gawron, M., Janczy, M., Król, D., Smoleń, M. (2011). Lecznictwo uzdrowiskowe w Polsce w latach 2000-2010. Kraków: Urząd Statystyczny w Krakowie.

Dziewoński, K. (1962). Zagadnienia typologii morfologicznej miast w Polsce. Czasopismo Geograficzne, 33(4), 441-457.

Heffner, K. (2015). Obszary funkcjonalne miast - problemy z kształtowaniem i funkcjonowaniem obszarów wiejskich. Studia KPZK PAN, 161, 59-74.

Heffner, K., Rosner, A. (2005). Zróżnicowanie przestrzenne rozwoju gospodarczego na obszarach wiejskich w Polsce. Studia Obszarów Wiejskich, 229-241.

Hodge, I., Midmore, P. (2008). Models of rural development and approaches to analysis, evaluation and decision-making. Economie Rurale, 307, 23-38.

Korcelli, P. (1976). Aglomeracje miejskie w systemach osadniczych. Wybrane hipotezy i perspektywy badawcze. Przeglad Geograficzny, 48(4), 589-599.

Krehl, A., Siedentop, S. (2018). Towards a typology of urban centres and subcenters - evidence from German city regions. Urban Geography, 40(1), 58-82.

Lehner, A., Blaschke, T. (2019). A Generic Classification Scheme for Urban Structure Types. Remote Sensing, 11(2), 1-21.

Mazur, M., Bański, J., Czapiewski, K., Śleszyński, P. (2015). Wiejskie obszary funkcjonalne - próba metodyczna wyznaczenia ich obszarów i granic. Studia Obszarów Wiejskich, 37, 7-36. 
Rosner, A. (ed.). (1999). Typologia wiejskich obszarów problemowych. Problemy Rozwoju Wsi i Rolnictwa. Ustawa $z$ dnia 28 lipca 2005 r. o lecznictwie uzdrowiskowym, uzdrowiskach i obszarach ochrony uzdrowiskowej oraz o gminach uzdrowiskowych (Dz.U. 2016, poz. 879).

Stanny, M. (2013). Przestrzenne zróżnicowanie rozwoju obszarów wiejskich w Polsce. Warszawa: Instytut Rozwoju Wsi i Rolnictwa PAN.

Stola, W. (1987). Klasyfikacja funkcjonalna obszarów wiejskich Polski. Próba metodyczna. Wrocław: PAN, IGiGP.

Śleszyński, P. (2016). Naukowe podstawy i praktyczne problemy klasyfikacji i delimitacji obszarów metropolitalnych. In: J. Szlachetko, R. Gajewski (eds.), Instytucjonalne formy współdziałania jednostek samorzadu terytorialnego na obszarach metropolitalnych. Gdańsk: Instytut Metropolitalny, Wydawnictwo Uniwersytetu Gdańskiego, 71-87.

Śleszyński, P. (2013). Delimitacja miejskich obszarów funkcjonalnych stolic województw. Przegląd Geograficzny, 85(2), 173-197.

Śleszyński, P., Komornicki, T. (2016). Klasyfikacja funkcjonalna gmin Polski na potrzeby monitoringu planowania przestrzennego. Przegląd Geograficzny, 88(4), 469-488.

Siemiński, J. (1979). Typologia gmin i typologiczny opis wybranych przykładów (typologia funkcjonalna gmin). Warszawa: Instytut Rozwoju Wsi i Rolnictwa PAN.

Swianiewicz, P. (1989). Społeczno-ekonomiczna typologia miast i gmin w Polsce. Rozwój Regionalny. Rozwój Lokalny. Samorząd Terytorialny, 19.

Traczyk, A., Wójcik, M. (2016). Innowacje w przemianach organizacyjno-przestrzennych sadownictwa rejonu grójeckiego. Społeczno-ekonomiczny Wymiar Innowacyjności na Obszarach Wiejskich, 173, 41-50.

Van Eetvelde, V., Antrop, M. (2009). A stepwise multi-scaled landscape typology and characterisation for trans-regional integration, applied on the federal state of Belgium, Landscape and Urban Planning, 91(3), 160-170.

Zioło, Z. (2016). Przedsiębiorczość w rozwoju układów lokalnych. Przedsiębiorczość - Edukacja [Entrepreneurship - Education], 12, 6-17.

Mateusz Ćwikła, PhD Eng., graduate of doctoral studies at the Faculty of Social Sciences of the Pedagogical University in Krakow, completed post-graduate studies at the Faculty of Law of the University of Economics, Law and Medical Sciences in Kielce, post-graduate studies at the Faculty of Civil Engineering and Architecture, graduate and undergraduate studies at the Faculty of Mathematics and Natural Sciences of Jan Kochanowski University in Kielce and engineering studies at the Faculty of Civil Engineering and Environmental Engineering of the Kielce University of Technology. He is licensed as an internal auditor of the ISO 14001 Environmental Management System (DEKRA) and the ISO 45001 Occupational Health and Safety Management System (URS). He completed the Theory of Solving Innovative Tasks course and has an international certificate of 1st degree TRIZ-MAN. The owner of a consulting company that provides services to institutions and companies in environmental protection regulations.

ORCID: https://orcid.org/ 0000-0002-7490-4307

\section{Address:}

Akademia Humanistyczno-Ekonomiczna w Łodzi

Wydział Zarządzania i Ekonomii

ul. Sterlinga 26

90-212 Łódź, Polska

e-mail: mcwikla@ahe.lodz.pl 